\title{
Correlation of the Coal Measures
}

$\mathrm{T}^{\mathrm{H}}$ HERE are two quite different aspects of Coal Measure correlation. In the first place, there is the desirability of dividing the thousands of feet of Coal Measure strata into zones or other subdivisions, which can be recognized in different coalfields and can be used in the comparison of sequences in different areas; in the second place, there is the demand of the mining engineer for criteria which will make it possible for him in a given area to identify individual coal seams or other rock beds. The broad zoning has its economic uses in the exploration of undeveloped areas in known coalfields and in the interpretation of deep borings into concealed coalfields. In these preliminary stages, it is sufficient to know what part of the Coal Measures has been reached, but as mining operations proceed, especially in areas where seams are much disturbed and faulted, there is need for much more precise information than can be gained from a study of zones which $n ., y$ themselves be hundreds of feet thick.

For many years, the methods of correlation of the Coal Measures lagged behind those used in other formations. When nearly every other system had been divided into palæontological zones, the Carboniferous rocks were still unzoned, and even then zonal methods were applied to the Lower Carboniferous before much progress was made with the Upper. Meanwhile, however, much success attended the work of geologists who used lithological characters and matched sequences with reference to the distribution of coals, and such workers as Wheelton Hind and Stobbs found valuable datum planes in the marine bands which mark temporary but widespread incursions of the sea into the area where Coal Measures were deposited.

The advances in Coal Measure correlation which have taken place in the past ten years were summarized in a discussion in Section C (Geology) of the British Association during the recent Blackpool meeting; geologists certainly can no longer be charged with neglecting the study of correlation in the rocks which are of most economic importance. It has to be emphasized, however, that the needs of the mining engineer can only be met by a scheme of correlation much more detailed than those developed in almost any other formation, and while zonal classifications of the Coal Measures are now available, efforts are being made to develop methods which will facilitate the identification of individual seams.

The most important fossils for the zoning of the Coal Measures are the plants and those lamelli- branchs (Carbonicola, Anthracomya and Naiadites) which are now believed to have lived in 'nonmarine' (if not wholly freshwater) conditions; while the marine bands form useful reference planes, they are too few and their fossils too restricted to afford a general basis for zoning. The non-marine shells have provided six major zones; these are now recognized in practically every coalfield in Britain, and a similar sequence is known on the Continent in coalfields so far afield as the Donetz basin. The precise limits of some of the zones are rather indefinite, but they appear to afford a reasonably secure basis for correlation. Several of the zones can be subdivided: Dr. W. B. Wright has used a number of sub-zones in working out the structure of the Lancashire coalfield, and Dr. J. Weir and Mr. D. Leitch have found that certain of these can be recognized in the Scottish coalfields.

In limited areas, these 'mussel' shells are often sufficiently characteristic of the roof of a seam to be an infallible means of identification. Some mussel bands have long been used in this way: in the highly disturbed anthracite area of South Wales, recognition of the worked seams by means of these faunas is now an established practice. The nomenclature of these excessively variable shells presents a difficult problem, but the closeness of correlation is greater than can be expressed by lists of specific names. Mr. S. G. Clift demonstrated this for horizons in Nottinghamshire and Scotland.

Detailed zoning by means of fossil plants is a still more recent feature of Coal Measure correlation in Great Britain, although on the Continent plant-zones were being used some years ago. The palæobotanical work of Kidston and others, however, laid the foundation of an accurate nomen. clature of the plants, and by collecting systematically from an established sequence in South Wales, Dr. Emily Dix has recently been able to subdivide the Coal Measures into zones which appear to be traceable over the whole of Britain. The results of this plant correlation in all the areas yet investigated substantiate the results based on the Lamellibranchs; as plants are usually abundant in those places where shells are rare, these two methods may often be regarded as complementary.

One striking result of the closer correlation of the sequences in various coalfields has been the recognition of the wide distribution of some characteristic bands. The great extent of certain marine bands (the equivalent of the Mansfield 
Marine Bed is known in practically every coalfield from Scotland to South Wales and Somerset) proves that occasionally very wide areas were submerged; the remarkable frequency with which thick coals occur at comparable horizons in different coalfields (as at the base of the Similis-Pulchra Zone) also suggests a comparative uniformity of conditions at certain stages in Coal Measure times. For some years, there had been a tendency to assume that the basins in which the Coal Measures were deposited were restricted in extent and more or less coincident with the existing coalfields: it was thus thought that the freshwater shells could not be used for correlation since they were only of local occurrence. Their wide distribution and the similarity of their sequences in different countries indicate at least a free communication between the areas.

Work on the spores of the coals has likewise tended to reveal the wide lateral extent of characteristic features. The classic investigation by Dr. L. Slater and others of the distribution of megaspores in the Silkstone and Better Bed coals of Yorkshire and the Arley of Lancashire, which confirmed the correlation of the Better Bed with the Arley, already put forward by Dr. D. A. Wray on stratigraphical grounds, clearly showed the value of these methods, and lent further support to the view that the main coals of these two coalfields were formerly continuous.
More recently, Dr. A. Raistrick has developed with remarkable success a technique for the examination of the microspore content of seams. He has applied this method to the coals of Northumberland and Durham, many of which appear to have a characteristic microspore content which persists over wide areas. He has recently been investigating the difficulties which are introduced by changes in the structure of the seams and in the chemical and physical properties of the coals. The various methods of using spores (both mega. spores and microspores) in correlation, and the problems which arise in that work, are also being explored by the Government Department responsible for fuel research (Mr. J. J. Walker and Dr. J. O'N. Millott gave an account of this work).

There can be little doubt that these methods will be of immense importance in the identification of seams, especially in the Lower and Middle Coal Measures, where the floral changes are most pronounced. In the highest Coal Measures, as Mr. G. A. Kellaway showed, the microspore con. tent of successive seams is much less varied, and these methods of correlation present greater diffculties. They are likely, however, to be of great use in the parts of the Coal Measures which are most worked. They will probably supplement rather than replace the use of the plants and shells, from which conclusions can generally be reached so much more rapidly.

\section{Bracken as a Weed}

THE Brake Fern or Bracken (Pteridium aquilinum) is an ancient plant of world-wide distribution in temperate and even tropical parts. Although a plant favouring the less dense woodlands and deeper soils, it may invade and dominate grass or heather even on shallow soils where the winters are not too severe or the summers too dry. This characteristic has made it a serious agricultural pest not only in Britain but also in Australia and New Zealand.

During the past forty or fifty years, the spread of bracken, especially in Scotland and Wales, has been so excessive that in many cases the available grazing land has been reduced by one half or more. This is not the only loss, however, for sheep which have been struck by the maggot fly (Lucilia sericata) take cover in dense bracken (which they normally avoid) and die there, although many could have been saved if treated in time. These carcasses are the breeding ground for more maggots. From the farmer's point of view, bracken (i) reduces the total grazing available and the number of sheep the ground should earry, (ii) leads to loss of sheep each of a value of $20 \mathrm{~s} .-30 \mathrm{~s}$. or more, and (iii) adds to the costs of management, as in the absence of bracken a shepherd and his dogs can work a greater area of sheep-run.

The spread of bracken is due to many causes : (a) mild winters, $(b)$ discontinuance of its use for thatching, litter, and as a source of potash for soap and manure, etc., (c) spore distribution, $(d)$ depopulation of rural areas, and (e) reduction of cattle and horse grazing. Horses and cattle do not eat bracken extensively - it possesses a cumulative poison in their case-but heavy animals tramping and grazing amidst the fronds damage it and encour. age grass. Pigs are the only animals which eat it they dig up the subterranean stems or rhizomes.

In a moderately dense patch of bracken there will be 40 tons of rhizome and about 10 tons of fronds to the acre. The huge amount of material built up each year is used for replenishing the 